\title{
Survey for the development of a standardization program for electronic medical records in dental clinic
}

\author{
Hyo-Jin Son ${ }^{1}$, Dong-Il Lim², Yu-Mi Park', and Mee-Kyoung Son ${ }^{3 *}$ \\ ${ }^{1}$ Dental Hygienist, Chosun University Dental Hospital, Gwangju, Republic of Korea \\ ${ }^{2}$ Computer Technician, Chosun University Dental Hospital, Gwangju, Republic of Korea \\ ${ }^{3}$ Professor, Department of Prosthodontics, College of Dentistry, Chosun University, Gwangju, Republic of Korea
}

In recent years, under the medical law, regulations on the protection of patient information, such as standardization of electronic medical records, compatibility between medical records, and information supplementation, are becoming stricter. Therefore, it is the time when advanced technology that can prevent damage, such as hacking, during transfer of medical records is necessary, so that strictly-restricted patient information can be encrypted and managed independently in a medical institution. In addition, the inefficiency of communication problems caused by the absence of a standardization system between dental clinics and dental hospitals and between dentistry and other medical institutions is improved through remote collaboration with patient consent, and the collaboration process using remote medical treatment will be established in the future to fulfill the requirement of an electronic treatment system. Therefore, it should be prioritized to determine what problems and improvement items are most required in the field using the survey results of electronic medical records, currently used in dental clinics and hospitals. Thus, content should be designed for the development of a standardized program for dental electronic medical records in the future.

Key Words: Electronic medical records; Program; Survey

(c) This is an open-access article distributed under the terms of the Creative Commons Attribution Non-Commercial License (http://creativecommons.org/licenses/by-nc/4.0) which permits unrestricted noncommercial use, distribution, and reproduction in any medium, provided the original work is properly cited.

\section{Introduction}

전자의무기록시스템은 환자의 기초정보부터 병력사항, 약물 반응, 건강상태, 진찰 및 입·퇴원 기록, 방사선 및 화상 진찰결 과 등으로 처방전달시스템인 order communication system (OCS)과 영상전송시스템인 picture archiving communication system (PACS)을 모두 포함하는 개념이다[1]. 이는 기존의 의무 기록을 디지털화하는 것과 함께 진료, 원무, 통계에 걸친 병원 의 전 업무를 자동화함은 물론 각종 진료정보와 음성, 영상 등의 다양한 데이터를 포함하는 포괄적인 의미로 의무기록 데이터센
터를 구축하는 일이다[2]. 현재 전자의무기록 시스템은 병원마 다 서식과 용어 등이 상이하며 의무기록 생산시스템과 의무기 록관리의 표준이 없는 상황에서 OCS, PACS, electronic medical record (EMR) 등의 시스템이 독립적으로 운영됨에 따라 많 은 문제점이 나타나고 있다[3]. 현행 의료법에서 제 23조의 2항 (전자의무기록의 표준화)은 호환성 및 보안(23조 1항)을 기반 으로 효율성과 통일성 있게 관리·활용될 수 있는 전자의무기록 시스템의 표준화를 공시하고 있다. 그러나 현재 국내에서 사용 하는 전자의무기록시스템은 기존의 수기기록을 전산화시키는 'Paperless' 개념에 충실하게 만들어진 시스템으로 대부분 입력

Received July 28, 2021; Accepted September 7, 2021

${ }^{*}$ Corresponding author: Mee-Kyoung Son, Department of Prosthodontics, College of Dentistry, Chosun University, 303, Pilmun-daero, Donggu, Gwangju 61452, Republic of Korea.

Tel: +82-62-220-3825, Fax: +82-62-220-3825, E-mail: son0513@chosun.ac.kr 
의 편의성을 위해 free text로 기록할 수 있도록 되어 있다 보니 정보들이 구조화, 표준화되어 있지 않고 약어나 오타로 인한 정 보의 오류가 많이 발생하며, 의료 분쟁 시 절대적인 효력을 발생 하는 전자의무기록의 사후 위·변조 문제로 인해 많은 논란이 되 고 있다[4]. 따라서 전자의무기록의 표준화와 함께 수정기록을 확인하고 보완을 강화할 수 있는 방안 마련이 시급하다. 더불 어 〈의료법 제 19 조의 환자의 정보누설금지조항〉에 의하면, 최 근 환자정보보호에 대한 규제가 엄격해지고 있다. 엄격히 제한 되는 환자 정보를 암호화하여 의료기관 내에서 자체적으로 안 전하게 관리할 수 있도록 진료 기록부 이송 시 해킹 등의 피해를 방지할 수 있는 선진기술이 필요한 시점이다. 또한 치과의원-치 과병원, 치과-타 의과기관 간의 표준화 시스템 부재로 인해 발 생하는 소통부재의 비효율성을 환자 동의 하에 원격협진을 통 하여 개선하고, 향후 원격 의료를 통한 협진 프로세스를 전자 진 료체계로 구축함이 요구된다[5,6].

본 연구에서는 향후 표준화된 치과 전자의무기록의 시스템 구축을 위해 현재 치과대학병원 및 치과의원에서 사용하는 전 자의무기록의 실태를 조사하여 현장에서 요구되는 문제점과 개 선사항이 무엇인지 파악하고, 이를 기반으로 향후 치과 전자의 무기록의 표준화 프로그램 개발을 위한 필요 콘텐츠를 설계함 에 있어 기초자료를 제공하고자 하였다.

연구의 구체적 목적으로는 첫째, 전산프로그램 담당인력의 일반적인 특성을 조사하고, 둘째, 대학병원 및 치과병·의원의 전산프로그램 현황을 분석하고자 하였다. 셋째, 설문내용을 토 대로 각 치과병·의원에서 사용하고 있는 전자의무기록 시스템 의 문제점을 파악하고 표준화된 치과전산 프로그램의 향후 개 발에 대한 인식을 종합·분석하고자 하였다.

\section{Materials and Methods}

\section{연구 설계}

본 연구는 온라인 및 오프라인을 이용한 자료검색을 바탕으 로 다양한 치과전산프로그램의 기능을 우선 수합하고, 이를 바 탕으로 설문지를 개발하였다. 설문지는 크게 3 가지 즉, 1 . 조 사대상자의 일반적 특성, 2. 현재 사용하고 있는 전산프로그램 에 대한 실태, 3. 미래 개발된 전산프로그램에 대한 의견으로 구분되어 개발되었으며, 개발된 설문조사 문항은 그림과 같다 (Supplement Fig. 1; available online only).

\section{연구 대상 및 방법}

본 연구를 위한 설문조사는 치과대학병원과 치과병·의원으
로 구분되어 조사되었다. 전국 11 개 치과대학부속 치과병원이 조사되었고, 치과병·의원은 대학치과병원을 제외한 대형병원과 일반 개인치과 의원이 조사되었다.

설문지는 치과대학병원은 전산 및 보험청구 담당자에게, 치 과병·의원은 대한치과의사협회 소속의 치과의원을 운영하고 있 는 원장에게 문자를 통해 발송되었다. 설문지는 대상자가 작성 하는 즉시 회신되는 방식으로 수합되어 분석되었다.

\section{Results}

\section{조사대상자의 일반적 특성}

본 설문은 11 개 치과대학병원에서 18 명, 34 개 치과병·의원 에서 34명으로 총 52명이 조사대상자로 참여하였다. 조사대상 자는 전산의무기록을 직접 사용하고 있는 인력으로 치과전산 담당 또는 보험을 직접 청구하고 있는 인력을 대상으로 하였다. 설문에 응한 조사대상자는 치과대학병원에서는 남성이, 치과 병·의원에서는 여성이 차지하는 비율이 높았고, 평균 근무년수 는 14년으로 나타났다. 조사대상자의 근무지역은 광역시 이상 의 대도시, 중소도시, 군단위 또는 농어촌으로 구별하여 조사되 었고 결과는 치과대학병원의 경우 $50.0 \%$ 가 광역시 이상의 대도 시, 치과의원은 $79.4 \%$ 가 광역시 이상의 대도시로 가장 많이 차 지하였다. 전문적인 치과전산프로그램 담당자의 상주 여부에 대해서는 치과대학병원의 경우 $100 \%$ 가 상주하고 있다고 응답 한 반면, 치과병·의원은 $65 \%$ 가 상주하지 않는다고 응답하였다. 2종 이상의 치과전산프로그램 사용 경험 여부에 대해서는 치과 대학병원 및 치과병·의원 모두 94.4\%가 ‘예’라고 답하였다. 반 면, 치과전산프로그램 교육을 정식으로 받은 경험이 있는지를 묻는 설문에 대해서는, 치과대학병원 근무자는 $94.4 \%$ 가 경험 이 있다고 답한 반면, 치과병·의원 근무자는 $61.8 \%$ 만 경험이 있 다고 답하였다. 조사대상자의 업무부서는 진료팀(치과의사, 치 과위생사 등), 전산팀, 행정팀으로 구분하여 조사하였으며 치 과대학병원과 치과병·의원 모두 진료팀의 비율이 각각 $76.4 \%$, 64.7\%로 가장 높게 나타났다(Table 1).

\section{치과전산프로그램 관련 현황조사}

\section{전산프로그램 및 영상 프로그램 사용 현황}

치과전산프로그램 사용 여부에 대해서는 치과대학병원은 $100 \%$, 치과병·의원은 $97 \%$ 로 대부분 사용하고 있는 것으로 나 타났다. 사용하는 치과전산프로그램으로는 치과대학병원의 경 우는 자체개발 사용(88.9\%)이 높게 나타난 반면, 치과병·의원은 하나로, 앤드컴, 덴트웹, 두번에 등 다양한 프로그램을 구입하여 
Table 1. General characteristics of the subjects

\begin{tabular}{lc}
\hline \multicolumn{1}{c}{ Variable } & Value $(\mathbf{a} / \mathbf{b})$ \\
\hline Sex & \\
Male & $66.7 / 47.1$ \\
$\quad$ Female & $33.3 / 52.9$ \\
Working area & \\
$\quad$ Big city & $50 / 79.4$ \\
$\quad$ Medium city & $44.4 / 14.7$ \\
$\quad$ Small city or country & $5.6 / 5.9$ \\
The existence of computing program specialist & \\
Have & $100 / 35$ \\
$\quad$ Don't have & $0 / 65$ \\
The experience in using two or more types of & \\
dental computer programs & \\
Have & $94.4 / 94.4$ \\
Don't have & $5.6 / 5.6$ \\
The experience of dental computer program training & \\
$\quad$ Have & $94.4 / 61.8$ \\
Don't have & $5.6 / 38.2$ \\
Working department of subjects & \\
Medical team & $76.4 / 64.7$ \\
Computing team & $11.8 / 11.8$ \\
Administration team & $11.8 / 11.8$ \\
Insurance team & $0 / 5.8$ \\
Etc. & $0 / 5.8$ \\
\hline
\end{tabular}

Values are presented as percent.

a, University dental hospital; b, Dental hospital or clinic.

사용하고 있는 것으로 나타났다. 병원 내 영상(X-ray, computed tomography [CT] 등) 프로그램으로는 치과대학병원의 경 우는 인피니티를, 치과병·의원 경우는 바텍을 사용하는 경우가 높게 분석되었다. 현재 치과전산프로그램 사용기한에 대해서는 대부분 5년 이상 사용하는 것으로 나타났으며, 병원 내 영상 $(\mathrm{X}-$ ray, CT 등) 프로그램의 연동 가능 여부에 대해서는 치과대학병 원은 $83.3 \%$, 치과병·의원은 $97 \%$ 가 연동되는 것으로 나타났다. 병원 내 처방프로그램 교체 횟수는 교체하지 않았거나 1회 교체 가 가장 많이 나타났으며, 현재 사용중인 프로그램의 수정 경험 여부는 치과대학병원의 경우는 6회 이상 수정이 $72.7 \%$ 로 높게 나타났고 치과병·의원은 수정하지 않고 사용하고 있는 경우가 가장 높게(41\%) 나타났다(Table 2).

\section{프로그램 연동 여부 및 청구 생성 여부}

지정된 의과병원과 컨설트 가능성 또는 프로그램 연동 가능 여부에 대해서는 대학병원의 경우는 연동되지 않음이 $66.7 \%$, 치과병·의원은 $76 \%$ 로 응답하였다. 인근 치과전문의와 컨설트 및 연동가능성에 대해서는 치과대학병원의 경우는 연동되지 않 음이 88.9\%, 치과병·의원은 $91 \%$ 로 나타났다. 건강보험, 자보, 산재, 보훈 관련 청구 생성 여부에 대해서 4 가지 모두 생성가능
Table 2. Dental records program and radiograph imaging program usage

\begin{tabular}{lc}
\hline \multicolumn{1}{c}{ Variable } & Value $(\mathbf{a} / \mathbf{b})$ \\
\hline Type of dental computer programs & \\
Self-develoment & $88.9 / 15$ \\
Andcom & $5.6 / 15$ \\
Hanaro & $0 / 24$ \\
I-pro & $0 / 18$ \\
Dentweb & $0 / 9$ \\
Doobunae & $0 / 9$ \\
Lipo-ex & $0 / 3$ \\
Das & $0 / 3$ \\
Type of radiograph imaging programs & \\
Infiniti & $55.6 / 15$ \\
M-view & $11.1 / 0$ \\
Pacsplus & $5.6 / 0$ \\
Z-pacs & $5.6 / 0$ \\
Pointnix & $5.6 / 15$ \\
Vatek & $0 / 29$ \\
Easydent & $0 / 12$ \\
Used period of dental computer programs & \\
Within 1 year & $0 / 12$ \\
1-3 years & $27.8 / 12$ \\
More than 5 years & $72.2 / 76$ \\
Porgram linkage function & \\
Have & $83.3 / 97$ \\
Don't have & $16.7 / 3$ \\
Number of prescription program changes & \\
None & $33.3 / 59$ \\
One time & $33.3 / 26$ \\
More than 2 times & $11.1 / 9$ \\
Number of program modifications & \\
None & $11.1 / 41$ \\
Less than 5 times & $16.7 / 25$ \\
More than 5 times & \\
\hline
\end{tabular}

Values are presented as percent.

a, University dental hospital; b, Dental hospital or clinic.

이 치과대학병원은 $61.1 \%$, 치과병·의원은 $59 \%$ 로 나타났고, 프 로그램 연동된 재고 프로그램 기능 여부에 대해 치과대학병원 은 $61.1 \%$ 가 '있다'라고 답하였고, 치과병·의원은 $47 \%$ 가 '모른 다’로 응답하였다. 금연환자 진료프로그램(상담, 처방, 보험전송 등) 연동 여부에 대해서는 치과대학병원은 $61.1 \%$ 가 '있다'라고 응답한 반면, 치과병·의원에서는 38\%만이 '있다'라고 답하였 다. 원내 프로그램과 drug utilization review (DUR) 연동 여부 에 대해서는 치과대학병원의 경우 $94.4 \%$, 치과병·의원은 $71 \%$ 가 연동된다고 응답하였다. 환자관리 customer relationship management 기능(commercial message, social network service 등) 여부에 대해서는 치과대학병원의 경우 $72.2 \%$, 치과 병·의원은 $82 \%$ 가 기능이 있다고 응답하였다. 홈페이지 연동 예 
약관리 기능에 대해서는 치과대학병원의 경우 $22.2 \%$, 치과병. 의원은 $21 \%$ 만 연동된다고 하였고, 현재 프로그램의 외부 해킹 피해 여부에 대해 치과대학병원은 $5.6 \%$. 치과병·의원은 $9 \%$ 가 경험이 ‘있다'라고 응답하였다. 현재 프로그램에 국가보훈환자 에 대한 정보 연동여부에 대해서는 치과대학병원은 $5.6 \%$, 치과 병·의원은 $21 \%$ 가 연동되는 것으로 나타났다(Table 3 ). 현재 사 용중인 치과전산프로그램의 장점에 대해서는 다양한 의견을 답 하였다. 치과대학병원과 치과병·의원에서 각자 사용하고 있는 프로그램에 대한 장단점을 정리한 표이다(Table 4, 5).

\section{프로그램 개발관련 설문조사}

\section{표준화된 치과전산 프로그램 필요 여부}

미래 표준화된 치과전산프로그램 개발의 필요성에 대해서는 치과대학병원은 각각 $83.3 \%$, 치과병·의원은 $71 \%$ 가 '절대적으 로 필요하다' 또는 ‘필요하다'라고 응답하였다. 미래 표준화된 치과전산프로그램 개발의 필요성에 대해 '필요 없다' 또는 '그다 지 필요하지 않다'라고 대답한 대상자를 대상으로 필요성을 못 느끼는 이유가 현재 사용하는 프로그램이 충분하기 때문인지를 묻는 설문에서는 치과대학병원, 치과병·의원 모두 $66.7 \%$ '아니 요'라고 응답하였다. 그렇다면, 현재의 프로그램에 대해 충분치 않다고 느낌에도 불구하고 왜 미래의 표준화된 프로그램의 필 요성을 못 느끼는지에 대해서는 다양한 응답을 하였고 이를 정 리한 결과는 다음과 같다(Table 6). 미래 표준화된 치과전산 프 로그램개발의 필요성에 대해 '필요하다' 또는 '절대적으로 필요 하다'라고 대답한 대상자를 대상으로 현재 사용하고 있는 전자 프로그램에 대한 불편한 점은 무엇인지 설문 응답 중 복수응답 이 가능하게 체크하도록 하였다(Table 7). 전자프로그램을 사용 하지 않고 수기록으로 하는 치과병·의원의 경우, 그 이유에 대 한 답으로는'해킹 등 개인비밀 노출에 대한 불안 때문'과 '관습 적으로 편리해서'라고 응답하였다. 현재 보험청구에는 어떤 프 로그램을 사용하는지에 대한 설문에서는 치과대학병원은 50\% 가 자체개발, 치과병·의원은 $20 \%$ 가 두번에로 가장 많았다. 향 후 희망사항을 담은 표준화된 프로그램이 개발된다면 사용의 향이 있는지에 대해서는 치과대학병원은 $84 \%$, 치과병·의원은 $62 \%$ 가 '예’라고 응답하였다.

\section{블록체인 기술에 대한 인식}

블록체인 기술에 대해 들은 바가 있는가에 대해서는 치과대 학병원은 $67 \%$, 치과병·의원은 $76 \%$ 가 ‘예'라고 응답하였다. 추 후 개발되는 치과전산 표준프로그램에 블록체인 기술이 정보보 안 및 보호에 적용되었을 때 안전하다고 생각하는가를 묻는 설 문에는 치과대학병원은 $61 \%$, 치과병·의원은 $47 \%$ 가 '예'라고
Table 3. Ability to link with external programs

\section{Variable}

Value $(\mathbf{a} / \mathbf{b})$

Between dental and medical consult program

Have

$33.3 / 24$

Don't have

$66.7 / 76$

Between external dental hospital and clinic

Have

$11.1 / 9$

Don't have

$88.9 / 91$

Between Health insurance, automobile insurance, occupational health and safety insurance, Veterans All possible veterans excluded

$61.1 / 59$

Etc.

$38.9 / 26$

$0 / 15$

Imaging program link functionality

Have

$61.1 / 26$

Don't have

$11.1 / 26$

Don't know

$27.8 / 47$

Smoking cessation program link functionality

Have

$61.1 / 38$

Don't have

$27.8 / 24$

Don't know

$11.1 / 38$

DUR program link functionality

Have

94.4/71

Don't have

$5.6 / 29$

CRM link functionality

Have

$72.2 / 82$

Don't have

$27.8 / 18$

Homage linked reservation fuction

Have

$22.2 / 21$

Don't have

Don't know

$5.6 / 21$

Haking damage experience

Have

$5.6 / 9$

Don't have

$77.8 / 76$

Don't know

$16.7 / 15$

Interworking fuction for national veterans

Have

$5.6 / 21$

Don't have

$61.1 / 35$

Don't know

$33.3 / 44$

Values are presented as percent.

DUR, drug utilization review; CRM, customer relationship management; a, University dental hospital; b, Dental hospital or clinic.

응답하였다. 블록체인 기술이 적용된 치과전산 표준프로그램이 개발된다면, 교체할 의향이 있는지에 대해서는 치과대학병원은 $44 \%$, 치과병·의원은 $62 \%$ 가 ‘아니요'라고 응답하였다. 교체할 의사가 없다면 그 이유는 안정성의 문제, 현재 시스템만족, 비용 부담 등 다양한 이유로 응답하였다(Table 8). 
Table 4. Advantages and disadvantages of electric medical record system at university dental hospital

\begin{tabular}{|c|c|}
\hline Advantages & Disadvantages \\
\hline $\begin{array}{l}\text { Can be supplemented if necessary } \\
\text { - Can be reflected user requirements quickly } \\
\text { - Modifications can be made at any time to suit complex } \\
\text { hospital conditions } \\
\text { - Easy access to information on the patient's entire medical history } \\
\text { with dentistry in a general hospital } \\
\text {. Convenient because it is a familiar program }\end{array}$ & $\begin{array}{l}\text { - Since general management, OCS, and billing programs are developed } \\
\text { in different languages, maintenance is difficult } \\
\text { - Can't link with other programs } \\
\text { - Not reflect the health insurance review and assessment service } \\
\text { - As it is optimized for medicine, there is a limit to application in } \\
\text { dentistry } \\
\text { - It's been a long time since developed, It cannot cope with changing } \\
\text { situations } \\
\text { - Program errors occurs oftenly } \\
\text { - Insufficient program management personnel } \\
\text { - It takes a long time to correct or supplement when a problem occurs } \\
\text { - Limits of insurance qualification classification according to diversified } \\
\text { insurance and copay } \\
\text { - Limits of computational control according to a certain rate of dental } \\
\text { prescription } \\
\text { - Limits of linkage between purchase and fee management of general } \\
\text { affairs }\end{array}$ \\
\hline
\end{tabular}

OCS, order communication system.

Table 5. Advantages and disadvantages of electric medical record system at dental hospital or clinic

\begin{tabular}{|c|c|}
\hline Advantages & Disadvantages \\
\hline $\begin{array}{l}\text { - Reservation charting and accounting statistics are possible } \\
\text { - Well explained at the bottom of the claim } \\
\text { - Program stability } \\
\text { - In case of claiming insurance, it informs whether or not to } \\
\text { modify it according to various conditions } \\
\text { - You can view all medical treatments at once and check all } \\
\text { appointment schedules } \\
\text { - Program errors can be immediately corrected by resident } \\
\text { program developer in the hospital } \\
\text { - Simple and easy } \\
\text { - Request for consultation with other departments is smooth and } \\
\text { function expansion is easy } \\
\text { - Insurance management and electronic charts are possible } \\
\text { one-stop } \\
\text { - Other programs can be linked } \\
\text { - It is possible to check systemic medical history } \\
\text { by linking with medical } \\
\text {. Convenient as you can view the billing and payment treatment } \\
\text { screens at the same time } \\
\text { - Better than other programs and the best detail } \\
\text { - Lots of convenient features } \\
\text { - Easy to use by many dentists } \\
\text { - Helped in the initial opening } \\
\text { - Simple and fast insurance claim process } \\
\text { - Up-to-date information and features are available with continuous } \\
\text { updates } \\
\text { - Easy to consult with medical }\end{array}$ & $\begin{array}{l}\text { - Uncomfortable to use and outdated } \\
\text { - Upgraded for years, but couldn't keep up with the demands of the } \\
\text { operator (Consultation, video) } \\
\text { - It is a little difficult to get used to at first due to various functions } \\
\text { - Inconvenient when computing errors occur } \\
\text { - Cannot be linked with other hospitals } \\
\text { - When it doesn't work, you need to ask the vendor for help } \\
\text { - Heavy-duty system operation due to versatility } \\
\text { - Difficulty using electronic charts because real-time backup is not } \\
\text { available and video images are large } \\
\text { - Need to supplement medical-oriented charts } \\
\text { - It is not smooth when two or more programs in the industrial } \\
\text { complex are linked. } \\
\text { - complicacy } \\
\text { - Intermittent breaks, it takes time to change programs } \\
\text { - Too many clicks to save } \\
\text { - Whether it is interoperable to enter an external program by } \\
\text { clicking several times } \\
\text { - Simple but there is a range that is not allowed for each case, } \\
\text { so the claim is a little ambiguous. } \\
\text { - Takes up network resources and instability of backup } \\
\text { - New chart and first visit medical records must be duplicated }\end{array}$ \\
\hline
\end{tabular}


Table 6. Reasons about the unnecessity of future standardized programs

\begin{tabular}{ll}
\hline \multicolumn{1}{c}{ Dental university hospital } & \multicolumn{1}{c}{ Dental clinic } \\
\hline Security problem & . State-controlled uniformization of medical treatment is likely to occur. \\
- In order to standardize and distribute programs in all hospitals, & $\cdot$ Regular updates may be delayed if standardized \\
budget, manpower and technical problems must be resolved & $\cdot$ Problems may arise in building customized services depending on the \\
- Medical standardization must precede & size of the hospital or the difference in computing facilities \\
\hline
\end{tabular}

Table 7. Complains by electric medical record program in use

\begin{tabular}{ll}
\hline \multicolumn{1}{c}{ Dental university hospital } & \multicolumn{1}{c}{ Dental clinic } \\
\hline - Discomfort occurs in linkage with insurance claim & $\cdot$ Discomfort occurs in linkage with insurance claim \\
- Repeated questions and records for each patient due to the & $\cdot$ Technical problems of items not included in the current program \\
absence of medical information & $\cdot$ Impossible to deal with errors immediately \\
- Discomfort occurs in linkage with insurance claims due to poor & \\
adaptability of the doctor/recorder & \\
- Technical problems of items not included in the current program & \\
- Impossible to deal with errors immediately
\end{tabular}

Table 8. Standardized dental computer program and blockchain awareness

\begin{tabular}{lc}
\hline \multicolumn{1}{c}{ Variable } & Value $(\mathbf{a} / \mathbf{b})$ \\
\hline Need for a standardized dental computer program \\
Yes \\
No & $83.3 / 71$ \\
Type of insurance program & $16.7 / 29$ \\
Self-development & \\
Doobunae & $50 / 9$ \\
I-pro & $0 / 20$ \\
Endwin & $0 / 12$ \\
Hanaro & $0 / 14$ \\
Etc. & $0 / 15$ \\
Don't know & $28 / 15$ \\
Use intention of standarized program in the future & $22 / 15$ \\
Yes & \\
No & $84 / 62$ \\
Awareness of blockchain & $16 / 38$ \\
Yes & \\
No & $67 / 76$ \\
Awareness about blockchain stability & $33 / 24$ \\
Yes & \\
No & $61 / 47$ \\
Intention to use a dental standardized program applied with blockchain \\
Yes & $44 / 62$ \\
No & $56 / 38$ \\
\hline
\end{tabular}

Values are presented as percent.

a, University dental hospital; b, Dental hospital or clinic.

\section{Discussion}

헬스케어는 기존의 치료 부문 의료서비스에 질병의 예방 및 관리 개념을 합친 전반적인 건강관리 사업을 말하며, 원격 검진 이나 방문 건강 컨설팅 등을 통해 인간의 건강과 직결되는 각종 서비스를 지칭한다 $[7,8]$. 최근 고령사회로 인해 인류의 수명이 증가하고, 이로 인해 다양한 사회적 변화가 동반되면서, 건강을 위협하는 요인 또한 다양해짐으로써 헬스케어에 대한 관심 또 한 고조되고 있다. 이러한 헬스케어의 영역에서 발생하는 인간 의 다양한 데이터들은 기하급수적으로 증가하고 있으며, 의료 기관, 연구기관, 제약회사 등 다양한 기관에서 그 데이터 간에 상호 운용성을 확보하고자 함이 헬스케어 커뮤니티의 숙원이라 할 수 있다[9].

반면 환자의 질병을 포함한 의료정보로부터 파생되는 데이 터의 공유는 연구나 의료분야의 발전을 위해 매우 유의미한 정 보임에도 불구하고, 다른 빅데이터의 활용과는 개인정보 보호 를 위하여 매우 제한되어왔다. 또한, 국내에 전자의무기록 시스 템이 도입되고 전자서명이 추가되고 이후 개인정보보호를 위한 시스템이 의료법 및 개인정보보호법에 의해 추가되어 왔다. 물 론 의료정보에 대한 보호를 위한 시스템적인 보완조치는 타당 하다. 하지만 헬스케어 서비스 체제에서 서비스와 관련된 정보 를 토대로 개인, 의료기관, 국가, 보험사들이 연결되고, 연구개 발, 제약회사, 의료기기 제조사 영역까지 확대된다면 방대한 데 이터 유통망이 구축될 수 있다[10]. 이렇게 구축된 네트워크에 서의 데이터는 개인의 헬스케어 데이터 소유권과 관계된 권리 행사를 정당화하고, 데이터 공유 또는 교환을 통해 헬스케어 산 업의 활성화를 할 수 있다는 장점이 있다. 
이러한 헬스케어 산업의 활성화를 위해 본 연구에서 국내 치 과전산프로그램 사용현황을 살펴본 결과 치과대학병원 및 치과 의원들에서 축적되고 있는 의료정보는 자체개발 할 시스템 또 는 상용중인 여러 치과전산프로그램 각각의 시스템에 저장되어 타 병원과의 연동성에 제한이 되었기 때문에 연동가능성 등이 확보된 표준화된 치과전산프로그램 개발이 필요하다. 또한, 최 근 관계법령에서 중요시하는 개인정보보호를 위한 안전성 확보 를 위한 부문도 고려해야 하는 상황이다.

블록체인 기술은 데이터에 대한 책임 및 투명성을 확보할 수 있다는 점에서 환자 개인정보보호 문제의 해법으로 제시되고 있다. 블록체인이 헬스케어의 혁신을 가져올 수 있는 세부 분야 로 의료정보 관리, 의약품 개발과 공급망 무결성, 보험 청구 관 리, 임상 연구정보 관리, 의료정보 보안 정도 등이 거론되고 있 다[11,12].

그러나 블록체인 기술은 수많은 의료 기회를 제공할 수 있지 만, 실제 헬스케어 분야에 도입하기 위해서는 해결해야 하는 사 항들이 있다. 현재 시점에서 하나의 블록에 저장할 수 있는 데이 터의 양이 한정적이고, 향후 발생되어 축적될 데이터의 크기를 감안한다면 블록체인에 저장되는 데이터의 크기와 형태에 대한 표준 프레임이 정해져야 한다[13]. 또한, 조사 과정에서 나타난 블록체인에 대한 인식 변화, 비용문제 등 선결해야 할 과제들이 있지만, 블록체인 기술은 의료정보를 효과적으로 기록하고 관 리할 수 있으며, 위·변조가 불가능하기에 안전하게 공유하고 개 인정보 유출에 대한 우려를 최소화 할 수 있으며, 의료정보의 효 율적인 활용과 의료산업의 발전을 위한 해결책이 될 수 있다.

본 연구를 통해, 현재 치과대학병원 및 치과의원들에서의 전 자의무기록 사용현황을 살펴봄으로써, 향후 전자의무기록 표준 화를 위해 필요한 요구를 분석하고, 표준화된 시스템 구축을 위 한 기반자료로 활용하고자 하였다. 연구 결과, 현재 사용하고 있 는 치과전산프로그램의 연동성에 있어 여러 가지 한계가 있음 이 확인되었다. 따라서, 다양한 프로그램 컨텐츠의 개발과 타 병 원과의 연동가능성 등이 확보된 표준화된 치과전산프로그램이 개발되고, 블록체인 기술을 통해 의료기관 관계자간의 의료 정 보 통합을 확대하고 지원함으로서 국민건강 데이터를 구축하고 이를 통해 국민건강증진에 기여할 수 있다는 점에서 더 많은 연 구와 활용이 필요할 것으로 기대된다.

\section{Acknowledgements}

This study was supported by research fund from Chosun University, 2020.

\section{Conflicts of Interest}

The authors declare that they have no competing interests.

\section{ORCID}

\author{
Hyo-Jin Son \\ https://orcid.org/0000-0002-9553-5336 \\ Dong-Il Lim \\ https://orcid.org/0000-0002-3603-2640 \\ Yu-Mi Park \\ https://orcid.org/0000-0002-7341-6600 \\ Mee-Kyoung Son \\ https://orcid.org/0000-0001-9225-1744
}

\section{References}

1. Hong KA, Oh JY, Um KH, Kim SM. A study on the factors affecting EMR system users satisfaction- focused on the EMR systems operated by large-scale hospitals. Health Serv Manag Rev 2009;3:76-86.

2. Wang KH. Survey on hospital information systems and their influencing factors in Korea [Thesis]. Seoul: Yonsei University; 2006.

3. Lee JY, Kim Y, Kim G. A study on the analysis and methods to improve the medical records management in a large university hospital. J Korean Soc Arch Rec Manag 2013;13:107-134. doi: 10.14404/JKSARM.2013.13.1.107.

4. Yoo YC, Park SY, Jeong JW, Kim JW, Song BG. A study on the electronic medical record system and cosmos block chain. Korean J Ind Secur 2019;9:137-159. doi: 10.33388/ kais.2019.9.2.137.

5. Yang JS, Lee YS, Hong YS. Implementation of secured remote EMR medical information using encryption algorithm. J Inst Internet Broadcast Commun 2014;14:133-139. doi: 10.7236/JIIBC.2014.14.4.133.

6. Shin JY. The challenge of improving the collection and use of electronic medical records. Health Welf Policy Forum 2018;262:29-38.

7. Song JE, Kim SH, Chung MA, Chung KI. Security issues and its technology trends in u-healthcare. Electron Telecommun Trends 2007;22:119-129. doi: 10.22648/ETRI.2007. J.220112.

8. Kim NR. A study concerning the operation condition and direction of improvement of Korean u-healthcare [Thesis]. Asan: Soonchunhyang University; 2015.

9. Park YR, Kim H, An EY, Kim HH, Kim JH, Park RW, et al. Establishing semantic interoperability in the course of clinical document exchange using international standard 
for metadata registry. J Korean Med Assoc 2012;55:729740. doi: 10.5124/jkma.2012.55.8.729.

10. Yu HW, Lee ES, Kho WK, Han HS, Han HW. Blockchain technology for healthcare big data sharing. J Bigdata 2018;3:73-82.

11. Kim HR, Hong SP. A study on personal information protection in blockchain network. J Secur Eng 2018;15:81-92. doi: 10.14257/jse.2018.04.04.
12. Ko PS. A study on the utilization of medical information system using blockchain [Thesis]. Seoul: Soongsil University; 2019.

13. Kim GR, Lee DH. A study on the protection, integrated management and uses of medical data through blockchain technologies. Korean Commer Law Assoc 2019;37:279327. doi: 10.21188/CLR.37.4.7. 